\title{
KESIAPAN KABUPATEN PAMEKASAN SEBAGAI KABUPATEN LAYAK ANAK
}

\author{
Umi Supraptiningsih \\ Jurusan Syari'ah dan Ekonomi STAIN Pamekasan, Jln. Pahlawan KM. 04 \\ Pamekasan, email:umi@stainpamekasan.ac.id
}

\begin{abstract}
Abstrak:
Salah satu tugas pemerintah untuk memberikan fasilitas, baik secara fisik maupun non fisik demi terwujudnya perlindungan dan tumbuh kembang anak adalah dengan terwujudnya program pemerintah Kabupaten/Kota Layak Anak. Hasil penelitian yang disajikan dalam artikel ini menunjukkan bahwa Pemahaman tentang kabupaten/kota layak anak memberikan pengertian bahwa dalam rangka mewujudkan strategi pengembangan Kabupaten/Kota Layak Anak, diharapkan adanya komitmen bersama para stake holder dalam perwujudan KLA dan untuk mengetahui berbagai permasalahan anak yang muncul beserta upaya penyelesaian yang tepat. Penganggaran yang berasal dari Anggaran Pendapatan dan Biaya Daerah diusulkan kepada Tim Anggaran yang terdiri dari penganggaran Fisik, maupun Non fisik sudah dilaksanakan akan tetapi tidak dilakukan secara terpadu, masing-masing SKPD membuat rencana anggaran masing-masing. dan Target Pamekasan sebagai Kabupaten Layak Anak dapat terwujud dalam waktu kira-kira lima tahun.
\end{abstract}

Kata Kunci :

Kesiapan, Kabupaten Pamekasan, Kabupaten Layak Anak 


\section{Pendahuluan}

Pasal 27 ayat (1) UUD Tahun 1945 menyebutkan bahwa "Segala warga Negara bersamaan kedudukannya di dalam hukum dan pemerintahan dan wajib menjunjung hukum dan pemerintahan itu dengan tidak ada kecualinya". Artinya bahwa semua Warga Negara Indonesia tanpa ada perbedaan apapun mempunyai hak yang sama untuk mendapatkan perlindungan hukum. Dalam pasal 1 ayat (3) UUD Tahun 1945 juga menegaskan bahwa Negara Indonesia adalah Negara hukum. Konsekwensi dari pasal tersebut, maka Negara harus menjadikan hukum sebagai panglima dalam kehidupan berbangsa dan bernegara.

Banyaknya persoalan sosial yang jika kita tarik dengan penyelesaian hukum dapat berakibat pada terabaikannya hakhak perorangan atau individu, sedangkan hak-hak perorangan tersebut harus mendapatkan perlindungan dari Negara. Terutama perorangan tersebut adalah mereka yang secara hukum belum mempunyai kecakapan untuk bertindak sendiri dalam memperjuangkan hak-haknya, bahkan dapat dikategorikan sebagai "korban". Seperti misalnya anak-anak yang masih dibawah umur. Bagaimana sebenarnya Undangundang memberikan perlindungan terhadap anak-anak, dapat diberikan contoh dari pasal 1 ayat (2) Kitab Undang-Undang Hukum Perdata yang berbunyi : Anak yang ada dalam kandungan seorang perempuan, dianggap sebagai telah dilahirkan, bilamana juga kepentingan si anak menghendakinya. Mati sewaktu dilahirkan, dianggaplah ia tak pernah ada. Dari bunyi pasal tersebut menunjukkan bahwa bagaimana UU memberikan perlindungan terhadap anak mulai anak tersebut masih berupa janin. Selanjutnya pengaturan terhadap perlindungan anak diatur lebih lanjut dalam berbagai peraturan perundang-undangan antara lain dalam UndangUndang No. 23 Tahun 2002 tentang Perlindungan Anak. 
Negara sangat perduli terhadap anak-anak untuk dapat mewujudkan hak-haknya karena selain anak-anak sebagai generasi penerus bangsa, anak-anak juga sangat rentan menjadi korban. Bahkan yang menjadi penyebab atas hilangnya hak-hak anak tersebut salah satunya adalah orang-orang yang seharusnya berkewajiban untuk memberikan perlindungan terhadap anak-anak. Maraknya tingkat kekerasan terhadap anak, baik kekerasan fisik, psikis, bahkan kekerasan sexsual. Terjadinya kekerasan tersebut dapat terjadi dimanapun baik dalam rumah, lingkungan sekolah bahkan juga dapat terjadi dilingkungan sosial yang mana anak-anak ini sering bergaul dan bermain dengan sesamanya. Berbagai kasus anak-anak selalu terjadi peningkatan, pada tahun 2012 yang tercatat di Unit PPA Polres Pamekasan terdapat 23 kasus anak-anak yang berhadapan dengan hukum, sedangkan tahun 2013 terdapat 27 kasus, dan tahun 2014 sampai bulan Mei ini ada 9 kasus anak, baik anak-anak menjadi pelaku maupun sebagai korban. Sebagaimana kasus yang terjadi pada diri WL (kelas 2 SMKK) sepulang sekolah dia diajak temannya bermain kerumah teman laki-laki ternyata sesampai di rumah temannya, sudah ada 8 anak laki-laki di rumah tersebut sedang minum-minuman, si WL ini diajak untuk minum, hasilnya setelah tidak sadarkan diri terjadilah perbuatan pencabulan yang dilakukan oleh 8 lakilaki tadi. Ini salah satu kasus sebagai gambaran bahwa aktifitas anak-anak sepulang sekolah diperlukan aktifitas yang positif, setidaknya ada kegiatan yang benar-benar anak-anak tersebut tidak lagi mempunyai pemikiran/kegiatan yang negatif. Lebih memprihatinkan lagi ada sekitar 40 anak di bangku SMP mempunyai kebiasaan menyakiti tubuhnya, setelah dilakukan pendalaman hampir $80 \%$ anak-anak ini mengalami tekanan berat yang disebabkan oleh kondisi rumah tangga (orang tuanya bercerai, sering terjadi pertengkaran), Kasus yang dialami RKY, 14 tahun siswa kelas 2 SMP telah dilaporkan bibinya karena terjadi percekcokan dengan bibinya dan terjadi penganiayaan, begitu pula yang dialami DDN, 10 tahun, siswi 
kelas 3 SD ini telah mengalami trauma berat karena sejak usia 8 tahun dibawah kendali orang tua tirinya untuk selalu melakukan pencurian dibawah tekanan dan ancaman ${ }^{1}$. Peristiwa ini hanya sebagian kecil contoh yang terjadi di lingkungan kita, kondisi yang membuat anak-anak selalu terancam keselamatannya bahkan mendapat trauma yang berkepanjangan.

Seperti diketahui, sejak tahun 1990, Indonesia telah meratifikasi Konvensi Hak Anak (KHA) melalui Keppres Nomor 36 Tahun 1990. Dengan meratifikasi konvensi tersebut, maka Indonesia berkewajiban memenuhi seluruh hak anak sebagaimana tercantum KHA, melindungi seluruh anak serta mendengarkan pandangan/pendapat anak. Peringatan Hari Anak Nasional Tahun 2013 pada bulan Juli lalu, Bapak Presiden telah menegaskan kepada Gubernur, Bupati dan Walikota untuk memastikan kondisi wilayahnya makin layak bagi anak, antara lain dengan mengalokasikan anggaran yang cukup dari APBD untuk membangun taman bermain, ruang terbuka hijau, sarana olahraga, dan fasilitas lainnya yang bermanfaat dan dibutuhkan bagi tumbuh kembang anak, karena pada umumnya sarana dan prasarana tersebut semakin hari semakin berkurang karena terdesak oleh kepentingan bisnis, pemukiman dan perkantoran" ujar Linda Amalia Sari Gumelar, Menteri Pemberdayaan Perempuan dan Perlindungan Anak saat membuka kegiatan ini. ${ }^{2}$

Salah satu tugas pemerintah untuk memberikan fasilitas, baik secara fisik maupun non fisik demi terwujudnya perlindungan dan tumbuh kembang anak adalah terwujudnya program pemerintah Kabupaten/Kota Layak Anak. Sudah memasuki tahun ke - 8 sejak tahun 2006 dimulainya

\footnotetext{
${ }^{1}$ Data kasus anak-anak dampingan Pusat Pelayanan Terpadi Pemberdayaan Perlindungan Perempuan Dan Anak Kab. Pamekasan (peneliti sebagai koordinator Divisi Hukum)

2 ibid
} 
pengembangan Kabupaten/Kota Layak Anak (KLA), artinya suatu kabupaten dan kota yang mempunyai sistem pembangunan berbasis hak anak melalui pengintegrasian komitmen dan sumber daya pemerintah, masyarakat dan dunia usaha yang terencana secara menyeluruh dan berkelanjutan dalam kebijakan, program dan kegiatan untuk pemenuhan hak anak.

Kabupaten Pamekasan berdasarkan Keputusan Bupati Pamekasan Nomor 188/622/432.131/2013 tanggal 13 Desember 2013 telah membentuk gugus tugas menuju Kabupaten Layak Anak. Kabupaten Layak Anak merupakan kabupaten/kota yang mempunyai sistem pembangunan berbasis hak anak melalui pengintegrasian komitmen dan sumberdaya pemerintah, masyarakat dan dunia usaha yang terencana secara menyeluruh dan berkelanjutan dalam kebijakan, program dan kegiatan untuk menjamin terpenuhinya hak anak. Kunci sukses untuk mewujudkan kabupaten/kota layak adalah adanya keikhlasan dan ketulusan orang dewasa mengutamakan kepentingan terbaik anak. Kepentingan anak harus menjadi pertimbangan utama dalam proses penyusunan dan perencanaan pembangunan. Sehingga, hasil pembangunan dapat optimal untuk mempersiapkan suatu generasi yang tangguh. Pembangunan bidang pendidikan harus sinkron dengan pembangunan bidang kebutuhan pasar ketenagakerjaan. Serta Pembangunan bidang infrastruktur menyentuh pada pemenuhan kebutuhan anak dan penyediaan infrastruktur perkotaan mengutamakan kepentingan terbaik anak.

Kegiatan Pencanangan Kabupaten Layak Anak, diharapkan tidak hanya untuk tujuan seremonial tetapi kesempatan ini dimanfaatkan sebaik mungkin. Anak-anak membutuhkan tindakan nyata sekarang juga, lebih dari sekedar komitmen. Kebutuhannya tidak bisa ditunda-tunda seiring dengan pertumbuhan anak. Oleh karena itu semua pihak (baik orang tua, guru, masyarakat, para tokoh masyarakat dan 
pejabat) dituntut lebih dari sekedar berkomitmen tetapi harus terlibat dalam tindakan nyata pemenuhan hak-hak anak, khususnya kebutuhan fisik dan psikologisnya.

Tujuan yang ingin dicapai dalam penelitian ini, untuk mengetahui (1) Pemahaman pemerintah daerah tentang Kabupaten/Kota Layak Anak. (2) Proses penyusunan dokumen perencanaan dan penganggaran daerah Kab. Pamekasan tahun 2014. (3) Kesiapan pemerintah daerah Kab. Pamekasan dalam mewujudkan Pamekasan sebagai Kabupaten Layak Anak. Dan (4) Faktor-faktor pendukung dan penghambat dalam mewujudkan Kabupaten Pamekasan sebagai Kabupaten Layak Anak.

\section{Metode Penelitian}

Pendekatan dalam penelitian ini menggunakan pendekatan kualitatif (qualitative approach) karena data yang dikumpulkan lebih banyak menggunakan data kualitatif yakni data yang disajikan dalam bentuk verbal bukan dalam bentuk angka ${ }^{3}$ yang semaksimal mungkin berusaha mendeskripsikan realitas aslinya untuk kemudian data dimaksud dianalisis dan diabstraksikan dalam bentuk teori sebagai tujuan finalnya. Pada penelitian kualitatif juga ditandai dengan menggunakan metode pengumpulan data yang berupa participant observation dan indepth interview sebagai instrumen pengumpulan data utama.

Penelitian ini menggunakan jenis penelitian deskriptif. Penelitian deskriptif adalah untuk memberikan data yang seteliti mungkin tentang manusia, keadaan atau gejala yang lainnya.4 Metode deskriptif ini dimaksudkan untuk memperoleh gambaran yang baik, jelas, dan dapat memberikan

\footnotetext{
${ }^{3}$ Noeng Muhadjir, Metode Penelitian Kualitatif, (Yogyakarta: Rake Sarasin, 1996), hal., 29.

${ }^{4}$ Soerjono Soekamto, Pengantar Penelitian Hukum (Jakarta : UI Press, 1988), hal 42
} 
data seteliti mungkin tentang obyek yang diteliti. Dalam hal ini untuk menggambarkan Kesiapan Kabupaten Pamekasan dalam mewujudkan Pamekasan sebagai Kabupaten Layak Anak.

Dalam penelitian kualitatif, analisis data dilakukan baik bersamaan dengan pengumpulan data ataupun sesudahnya, dimana pekerjaan pengumpulan data dalam penelitian kualitatif harus dilakukan dengan pekerjaan menuliskan, mengedit, mengklasifikasi, mereduksi dan menyajikan data. ${ }^{5}$ Analisis data tersebut ditandai dengan proses analisis induktif, analisis tipologis, konseptualisasi dan interpretasi sehingga diperoleh temuan penelitian.

\section{Hasil Penelitian}

Pemahaman pemerintah daerah Kabupaten Pamekasan tentang Kabupaten/Kota Layak Anak

Dikatakan Kabupaten/Kota Layak anak adalah kabupaten/kota yang menyiapkan apa saja yang menjadi kebutuhan anak baik kebutuhan fisik dan non fisik. Sedangkan Kabupaten Layak Anak juga diartikan bahwa Kabupaten yang memenuhi indikator-indikator (ada 35 indikator) atau diartikan model pembangunan kabupaten/kota secara integratif dalam rangka pemenuhan hak-hak anak artinya semua pembangunan seperti pendidikan, kesehatan, infrastruktur, lingkungan keluarga dan masyarakat yang benar-benar sesuai dengan kebutuhan anak.

Lahirnya kebijakan KLA, diharapkan dapat menciptakan keluarga sayang anak, rukun tetangga dan rukun warga atau lingkungan yang peduli anak, kelurahan dan desa layak anak dan kecamatan atau kabupaten/kota yang layak bagi anak sebagai prasyarat untuk memastikan bahwa anak-anak tumbuh dan berkembang dengan baik, terlindungi haknya dan terpenuhi kebutuhan pisik dan psikologisnya. Untuk mewujudkan KLA tersebut, maka pemerintah kabupaten/kota

${ }^{5}$ Muhajir, Penelitian Kualitatif, hlm., 30 
perlu melakukan berbagai upaya pengintegrasian sumber daya, isu-isu perlindungan dan peningkatan kualitas anak ke dalam dokumen perencanaan dan implementasi pembangunan pemerintah, pemerintah provinsi dan pemerintah kabupaten/kota. Oleh karena itu maka perlu adanya panduan kebijakan KLA.

Pemahaman tentang kabupaten/kota layak anak memberikan pengertian bahwa dalam rangka mewujudkan strategi pengembangan Kabupaten/Kota Layak Anak, diharapkan adanya komitmen bersama para stake holder dalam perwujudan KLA dan untuk mengetahui berbagai permasalahan anak yang muncul beserta upaya penyelesaian yang tepat. Hal utama yang harus dilakukan dalam mewujudkan KLA adalah memberikan prioritas dalam perencanaan penganggaran daerah akan kebutuhan pendidikan, tumbuh kembang dan perlindungan anak baik secara fisik maupun non fisik.

Dalam rangka mewujudkan tercapainya KLA, tentunya dibutuhkan peranan para pihak, pihak-pihak yang berperan tersebut adalah :

1. Pemerintah

Pemerintah bertanggung jawab dalam merumuskan dan menetapkan kebijakan nasional dan memfasilitasi kebijakan KLA. Selain itu pemerintah juga melakukan koordinasi dalam pelaksanaan kebijakan KLA.

2. Asosiasi Pemerintah Kabupaten/Kota seluruh Indonesia APKSI/APEKSI sebagai jaringan komunikasi antar kabupaten/kota mempunyai posisi strategis untuk wadah bertukar pengalaman dan informasi antar anggota untuk memperkuat pelaksanaan KLA di masing-masing kabupaten/kota.

3. Pemerintah Kabupaten/Kota

Pemerintah kabupaten/kota bertanggung jawab dalam membuat kebijakan dan menyusun perencanaan, pelaksanaan, pemantauan, evaluasi, pelaporan, dan 
memobilisasi potensi sumber daya untuk pengembangan KLA.

4. Organisasi Non Pemerintah dan Organisasi Kemasyarakatan

Organisasi Non Pemerintah dan Organisasi Kemasyarakatan mempunyai peran penting dalam menggerakkan masyarakat untuk mendukung pelaksanaan KLA.

5. Sektor Swasta dan Dunia Usaha

Sektor swasta dan dunia usaha merupakan kelompok potensial dalam masyarakat yang memfasilitasi dukungan pendanaan yang bersumber dari alokasi Corporate Social Responsibility untuk mendukung terwujudnya KLA.

6. Lembaga Internasional

Lembaga internasional sebagai lembaga memfasilitasi dukungan sumber daya internasional dalam rangka mempercepat terwujudnya KLA.

7. Masyarakat

Masyarakat bertanggung jawab mengefektifkan pelaksanaan, monitoring, dan evaluasi program KLA dengan memberikan masukan berupa informasi yang obyektif dalam proses monitoring dan evaluasi.

8. Keluarga

Keluarga merupakan wahana pertama dan utama memberikan pengasuhan, perawatan, bimbingan, dan pendidikan dalam pemenuhan hak dan perlindungan anak.

Stakeholder yang telah ditetapkan sebagai gugus tugas dalam pelaksanaan dan perwujudan KLA Kabupaten Pamekasan berdasarkan Keputusan Bupati Pamekasan Nomor 188/622/432.131/2013 tanggal 13 Desember 2013 harus betulbetul faham tentang tugasnya masing-masing, maka dengan memahami tugas tersebut akan cepat terwujud apa yang menjadi kebutuhan dan hak-hak anak.

Pengembangan KLA mengacu pada Indikator KLA yang ditetapkan lebih lanjut dengan Peraturan Menteri Negara 
Pemberdayaan Perempuan dan Perlindungan Anak. Indikator KLA dibagi dalam dua kategoro yaitu Indikator Umum dan Indikator Khusus. Indikator umum adalah dampak jangka menengah dan jangka panjang dari pengembangan kebijakan KLA dimana Kementerian Negara Pemberdayaan Perempuan (KPP) dan Badan Pemberdayaan Perempuan di provinsi dan kabupaten/kota tidak terlibat secara langsung dalam upaya mencapai indikator tersebut. Dalam hal ini peran KPP lebih pada pembuatan kebijakan agar tercipta suatu keadaan yang kondusif dalam rangka mempercepat pencapaian indikator tersebut. Indikator khusus adalah dampak jangka pendek dan jangka menengah dari pengembangan kebijakan KLA dimana Kementerian Negara Pemberdayaan Perempuan (KPP) dan Badan Pemberdayaan Perempuan di provinsi dan kabupaten/kota terlibat secara langsung dalam upaya mencapai indikator tersebut.

Terdapat dua tugas pokok KPP yaitu pertama membuat kebijakan KLA dan kedua mempromosikan pelaksanaan kebijakan tersebut. Kebijakan perlindungan anak antara lain meliputi: Peraturan Menteri, Keputusan Menteri, Peraturan Daerah, Keputusan Bupati/Walikota, Instruksi Bupati/Walikota, Nota kesepahaman atau memorandum of understanding (MoU) dengan lembaga-lembaga yang secara langsung berhubungan dengan kegiatan KLA. Dengan demikian maka fokus kegiatan KLA yang dapat akan diukur adalah pembuatan kebijakan dan promosi agar kebijakan yang sudah dibuat dapat terlaksana. Upaya tersebut meliputi: (1) Pembuatan kebijakan KLA, (2) Promosi kebijakan KLA, (3) Fasilitasi, (4) Advokasi, (5) Sosialisasi, (6) Bimbingan teknis, (7) Komunikasi Informasi dan Edukasi (KIE), (8) Penggalangan sumberdaya pembangunan (ketenagaan, keuangan, sarana dan metoda), (9) Penelitian dan pengembagan (research and development), (10) Pengembangan model/ percontohan (pilot project), (11) Pelatihan hak anak. 
Dalam perspektif KHA, hak anak ditegaskan secara khusus yang meliputi hal-hal sebagai berikut:

a. mempunyai hak untuk tempat tinggal - pasal 27 menegaskan hak setiap anak atas kehidupan untuk pengembangan fisik, mental, spritual, dan moral. Untuk itu orang tua bertanggung jawab mengupayakan kondisi kehidupan yang diperlukan untuk mengembangkan anak sesuai dengan kemampuan. Kondisi seperti ini sangat berbeda yang dialami oleh anak jalanan yang tidak mempunyai tempat tinggal dan terputus dengan orang tua.

b. mempunyai hak untuk mendapatkan keleluasaan pribadi - tempat tinggal padat dan tumpang tindih di kota menjadikan anak merasa terganggu keleluasaan pribadinya. Kondisi seperti ini banyak dialami oleh anak-anak yang berasal dari keluarga miskin di kota, sehingga dampaknya adalah perasaan tertekan dan ketegangan pada diri anak. Keadaan ini dapat dikurangi bila orang tua peduli terhadap keluarganya. Perumahan padat dapat menjadi salah satu faktor dalam perlakuan buruk terhadap anak atau kekejaman dan perlakuan salah secara seksual.

c. mempunyai hak untuk mendapatkan rasa aman keamanan fisik dan psikososial merupakan hal penting bagi anak yang ada di kota. Lemahnya penegakan hukum, meluasnya kekejaman dan kejahatan mempunyai dampak yang kuat terhadap anak dan remaja.

d. mempunyai hak untuk mendapatkan lingkungan yang sehat - sanitasi buruk, kurangnya air bersih, kurangnya fasilitas toilet, dan banyaknya sampah memberi dampak yang serius terhadap kesehatan anak. Kondisi kota seperti ini menghadapi 
masalah serius terhadap tumbuh kembang anak, karena mereka mudah terjangkit penyakit cacar, diare, ISPA, TBC, dan penyakit lain yang sering dialami oleh warga yang tinggal di wilayah kumuh.

e. mempunyai hak untuk bermain - ini artinya tersedia areal hijau dan ruang terbuka untuk bermain. Lokasi tempat bermain dengan rumah khususnya untuk anak kecil dan anak dengan kecacatan.

f. mempunyai hak untuk mendapatkan pendidikan setiap anak mempunyai hak dan kesempatan yang sama memperoleh pendidikan, sehingga perlu mendapat perhatian pemerintah kota kepada anak-anak yang tinggal di tempat illegal, karena tempat mereka tidak dilengkapi sekolah, begitu juga dengan anak yang ada di wilayah kumuh biasanya kualitas sekolahnya sangat buruk.

g. mempunyai hak untuk memperoleh pelayanan transportasi umum - mengakses tranportasi umum yang baik untuk semua merupakan hal yang esensial. Untuk memenuhi hak anak, bagaimana pun transportasi yang aman adalah berjalan kaki, naik sepeda atau mengakses transportasi yang tidak menghasilkan polusi dan ramah anak. ${ }^{6}$

Untuk membangun inisiatif pemerintahan kabupaten/kota yang mengarah pada upaya transformasi Konvensi Perserikatan Bangsa-Bangsa tentang Hak Anak dari kerangka hukum ke dalam definisi, strategi, dan intervensi pembangunan seperti kebijakan, kelembagaan dan program yang layak anak.

Tujuan kebijakan Kabupaten/Kota Layak Anak adalah:

6 Save the Children, 1996:13-15 
a. Untuk meningkatkan komitmen pemerintah, masyarakat dan dunia usaha di kabupaten/kota dalam upaya mewujudkan pembangunan yang responsif terhadap hak, kebutuhan dan kepentingan terbaik bagi anak;

b. Untuk mengintegrasikan potensi sumber daya manusia, keuangan, sarana prasarana, metoda dan teknologi yang ada pada pemerintah, masyarakat serta dunia usaha di kabupaten/kota dalam mewujudkan hak anak;

c. Untuk mengimplementasi kebijakan perlindungan anak melalui perumusan strategi dan perencanaan pembangunan kabupaten/kota secara menyeluruh dan berkelanjutan sesuai dengan indikator KLA; dan

d. Untuk memperkuat peran dan kapasitas pemerintah kabupaten/kota dalam mewujudkan pembangunan di bidang perlindungan anak.

\section{Proses penyusunan dokumen perencanaan dan penganggaran daerah Kab. Pamekasan tahun 2014}

Kabupaten/Kota Layak Anak (KLA) adalah model pembangunan kabupaten/kota yang mengintegrasikan komitmen dan sumberdaya pemerintah, masyarakat dan dunia usaha dalam rangka memenuhi hak anak yang terencana secara menyeluruh (holistik) dan berkelanjutan (sustainable) melalui Pengarusutamaan Hak Anak (PUHA).

Ruang lingkup Kebijakan KLA meliputi pembangunan di bidang kesehatan, pendidikan, perlindungan, infrastruktur, lingkungan hidup dan pariwisata baik secara langsung maupun tidak langsung berhubungan dengan implementasi hak anak sebagaimana diatur dalam Undang-Undang Perlindungan Anak.

Kebijakan KLA mencakup aspek pembiayaan, ketenagaan, pengawasan dan penilaian, penelitian dan pengembangan serta keterwakilan aspirasi dan kepentingan 
anak dalam pengambilan keputusan pembangunan kabupaten/kota.

Oleh karena itu pemerintah memandang perlu adanya Kebijakan Kabupaten/Kota Layak Anak sebagai langkah awal dalam rangka menciptakan pembangunan yang peduli terhadap hak, kebutuhan dan kepentingan anak. Karena prinsip kebijakan KLA adalah mendorong kabupaten/kota agar menghormati hak anak yang diwujudkan dengan cara: (1) menyediakan akses pelayanan kesehatan, pendidikan, air bersih, sanitasi yang sehat dan bebas dari pencemaran lingkungan; (2) menyediakan kebijakan dan anggaran khusus untuk anak; (3) menyediakan lingkungan yang aman dan nyaman, sehingga memungkinkan anak dapat berkembang. anak dapat berekreasi, belajar, berinteraksi sosial, berkembang psikososial dan ekspresi budayanya; (4) keseimbangan di bidang sosial, ekonomi, dan terlindungi dari pengaruh kerusakan lingkungan dan bencana alam; (5) memberikan perhatian khusus kepada anak seperti yang tinggal dan bekerja di jalan, eksploitasi seksual, hidup dengan kecacatan atau tanpa dukungan orang tua; (6) menyediakan wadah bagi anak-anak untuk berperan serta dalam pengambilan keputusan yang berpengaruh langsung pada kehidupan mereka. ${ }^{7}$

Begitu pula dalam KTT Bumi di Rio de Janeiro, Brasil 1992, para Kepala Pemerintahan dari seluruh dunia menyepakati prinsip-prinsip Agenda 21 yaitu Program Aksi untuk Pembangunan Berkelanjutan. Kesepakatan di Bab 25 Agenda 21 ditujukkan untuk anak dan remaja yang secara khusus mendesak pemerintah: (a) melaksanakan programprogram untuk menjangkau sasaran-sasaran yang ditetapkan oleh pertemuan puncak dunia untuk anak; (b) menekankan partisipasi anak dalam pengelolaan lingkungan; (c) melaksanakan Konvensi Hak Anak; (d) memperluas pendidikan bagi anak, terutama anak perempuan; dan (e) memasukkan

${ }^{7}$ Innocenti Digest No.10/10/02:22 
semua kepentingan anak ke dalam semua kebijakan dan strategi yang sesuai dengan pembangunan berkelanjutan.

Kebutuhan fasilitas baik fisik maupun non fisik dalam rangka mewujudkan Pamekasan sebagai Kabupaten Layak Anak tentunya mengakomodir kebutuhan-kebutuhan di atas, perlu ada penganggaran yang memadai dan betul-betul tepat sasaran. Proses dalam penyusunan dokumen perencanaan dan penganggaran dilakukan dengan cara/proses sebagai berikut : dari Pertama kali SKPD mendapat surat permohonan Rencana Kerja (Renja) tahun depan bentuknya adalah program, selain itu ada juga surat permintaan Rencana Kegiatan dan anggaran yang diajukan kepada kasubag hukum dari Kantor Badan Pengelolaan dan Aset ini ini bentuknya adalah proposal atau TOR. Selanjutnya dari dua surat itu dilakukan verivikasi. Biasanya verivikasi dari Bapeda selalu disetujui namun dari Badan Pengelolaan dan kantor aset selalu ada koreksi. Setelah itu ada rapat pembahasan tim anggaran Rencana Kegiatan dan Anggaran yang melibatkan seluruh ortaker. Kemudian dibawa ke DPRD untuk dibahas. Hasil pembahasan dikirim ke Propinsi untuk dievaluasi, dan hasil evaluasi dibahas di DPRD, selanjutnya hasil pembahasannya dikirimkan kembali ke Propinsi. Terakhir setelah final ditetapkan oleh Bupati dalam bentuk Perda, selanjutnya ditetapkan dalam Daftar Pelaksana Anggaran (DPA).

Dalam perencanaan kegiatan yang harus betul-betul diperhatikan oleh masing-masing SKPD dan juga stakeholder yang tergabung dalam gugus tugas KLA Kab. Pamekasan, adanya pengarusutamaan gender (PUG) dan sensitifitas terhadap anak. Dari beberapa SKPD yang secara rutin setiap tahun anggaran sudah memasukkan pengarusutamaan gender (PUG) dan sensitifitas terhadap anak adalah Dinas Kependudukan dan catatan sipil, Dinas pendidikan, dinas sosial dan tenaga kerja, dan Badan Pemberdayaan Perempuan dan Keluarga Berencana. 
Penganggaran yang berasal dari Anggaran Pendapatan dan Biaya Daerah diusulkan kepada Tim Anggaran yang terdiri dari penganggaran berupa : Fisik, meliputi pengajuan shelter (rumah aman) berikut sarana dan prasarananya, Alat Permainan Edukasi (diajukan tiap tahun) sasaran atau penggunanya untuk kelompok Bina Keluarga Balita dan PAUD, pemberian makanan tambahan sekolah sasarannya untuk anak-anak Sekolah Dasar di 13 kecamatan se-Kabupaten Pamekasan. Non fisik, meliputi : Sosialisasi ke SKPD dan Tim Perencana, Rapat Kerja dengan instansi kerja terkait seperti dengan gugus tugas, sosialisasi dan pembentukan forum Anak, pendampingan melalui Pusat Pelayanan Terpadu Pemberdayaan Perlindungan Perempuan dan Anak.

Kesiapan pemerintah daerah Kab. Pamekasan dalam mewujudkan Pamekasan sebagai Kabupaten Layak Anak

Target Pamekasan sebagai Kabupaten Layak Anak dapat terwujud dalam waktu kira-kira lima tahun. Beberapa hal yang harus dipersiapkan baik kebutuhan fisik dan non fisik. Persiapan yang harus dilakukan adalah Peraturan Daerah atau Peraturan Bupati, Rencana Aksi daerah menuju Kabupaten Layak Anak, hal ini adalah hasil komitmen Satuan Kerja Pemerintah Daerah (SKPD). Selain itu yang harus dipersiapkan antara lain adanya kesamaan visi dengan instansi-instansi terkait seperti Badan Lingkungan Hidup, Pekerjaan Umum, Cipta Karya, sedangkan Badan Pemberdayaan Perempuan dan Keluarga Berencana berada di depan untuk mengkoordinasikan dan menyiapkan kebutuhan dari hak-hak anak dalam rangka menuju Kabupaten Layak Anak. Sudah sejak tahun 2010 Pamekasan dinobatkan sebagai Kabupaten Layak Anak, salah satu kriteria yang dipenuhi oleh Kabupaten Pamekasan yaitu telah terpenuhinya standart layanan kependudukan dan terpenuhinya pencatatan akta kelahiran bagi anak-anak. 
Pada UN Special Session on Children, Mei 2002, para walikota menegaskan komitmen mereka untuk aktif menyuarakan hak anak, dan merekomendasikan kepada walikota seluruh dunia untuk: pertama mengembangkan rencana aksi untuk menjadi kota ramah anak; dan kedua mempromosikan partisipasi anak sebagai aktor perubah dalam proses pembuatan keputusan di kota terutama dalam proses pelaksanaan dan evaluasi kebijakan pemerintah kota.

Pertemuan ini mendeklarasikan Gerakan Global yang membantu membangun suatu dunia yang layak bagi anak dengan 10 komitmen: (a) dahulukan kepentingan anak; (b) berantas kemiskinan: tanamkan investasi pada anak; (c)jangan sampai seorang anak tertinggal; (d) perawatan bagi setiap anak; (e) didiklah setiap anak; (f) lindungi anak terhadap penganiayaan dan eksploitasi; (g) lindungi anak dari peperangan; (h) berantas HIV/AIDS; (i) dengarkan anak dan pastikan partisipasi mereka; dan (j) lindungi bumi untuk anak.

Kebijakan Pengembangan KLA dilaksanakan berdasarkan prinsip-prinsip yang meliputi: (a) tata pemerintahan yang baik, yaitu transparansi, akuntabilitas, partisipasi, keterbukaan informasi, dan supremasi hukum; (b) non-diskriminasi, yaitu tidak membedakan suku, ras, agama, jenis kelamin, bahasa, paham politik, asal kebangsaan, status ekonomi, kondisi fisik maupun psikis anak, atau faktor lainnya; (c) kepentingan terbaik bagi anak, yaitu menjadikan hal yang paling baik bagi anak sebagai pertimbangan utama dalam setiap kebijakan, program, dan kegiatan; (d) hak untuk hidup, kelangsungan hidup, dan perkembangan anak, yaitu menjamin hak untuk hidup, kelangsungan hidup dan perkembangan anak semaksimal mungkin; dan (e) penghargaan terhadap pandangan anak, yaitu mengakui dan memastikan bahwa setiap anak yang memiliki kemampuan untuk menyampaikan pendapatnya, diberikan kesempatan untuk mengekspresikan 
pandangannya secara bebas terhadap segala sesuatu hal yang mempengaruhi dirinya. ${ }^{8}$

Ada empat prinsip kunci Konvensi Hak Anak yang menjadi dasar membangun Kabupaten/Kota Layak Anak : pertama Non Diskriminasi, Pelaksanaan dan pengembangan kebijakan KLA dilaksanakan dalam rangka perlindungan anak tanpa membedakan suku, ras, agama, jenis kelamin, status social, asal daerah, kondisi pisik maupun psikis anak. Kedua Kepentingan yang terbaik bagi anak, menjadikan kepentingan yang terbaik bagi anak sebagai pertimbangan utama dalam setiap pengambilan keputusan yang dilakukan oleh, pemerintah, badan legislatif, badan yudikatif dan lembaga lainnya yang berhubungan langsung maupun tidak langsung dengan anak; ketiga Hak untuk hidup, kelangsungan hidup dan perkembangan, Perlindungan hak asasi anak sebagai hak yang paling mendasar dalam kehidupan anak yang perlu dilindungi oleh negara, pemerintah, masyarakat, keluarga dan orang tua; keempat Penghargaan terhadap pendapat anak, Penghormatan atas hak anak untuk berpartisipasi dan menyatakan pendapatnya dalam penambilan keputusan terutama jika menyangkut hal-hal yang mempengaruhi kehidupan anak.

Prasyarat pengembangan KLA adalah : (1) Adanya Kemauan dan komitmen pimpinan daerah: membangun dan memaksimalkan kepemimpinan daerah dalam mempercepat pemenuhan hak dan perlindungan anak yang dicerminkan dalam dokumen peraturan daerah. (2) Baseline data: tersedia sistem data dan data dasar yang digunakan untuk perencanaan, penyusunan program, pemantauan dan evaluasi; (3) Sosialisasi hak anak: menjamin adanya proses penyadaran hak anak pada anak dan orang dewasa secara terus menerus; (4) Produk hukum yang ramah anak: tersusunnya peraturan perundangan yang sesuai dengan prinsip-prinsip perlindungan

\footnotetext{
8 Pasal 5 Peraturan Menteri Negara Pemberdayaan Perempuan dan Perlindungan Anak No. 11 Tahun 2011
} 
hak anak; (5) Partisipasi anak: tersedia wadah untuk mempromosikan kegiatan yang melibatkan anak dalam program-program yang akan mempengaruhi mereka; mendengar pendapat mereka dan mempertimbangkannya dalam proses pengambilan keputusan; (6) Pemberdayaan keluarga: adanya program untuk memperkuat kemampuan keluarga dalam pengasuhan dan perawatan anak; (7) Kemitraan dan jaringan: adanya kemitraan dan jaringan dalam pemenuhan hak dan perlindungan anak; (8) Institusi Perlindungan Anak: Adanya kelembagaan yang mengkoordinasikan semua upaya pemenuhan hak anak.

Begitu pula dibentuknya perangkat yang menyiapkan dan mendukung terlaksananya KLA di Kabupaten/Kota. Perangkat yang dimaksudkan antara lain melalui pembentukan gugus tugas KLA. Gugus Tugas KLA merupakan lembaga koordinatif yang beranggotakan wakil dari unsur eksekutif, legislatif, dan yudikatif yang membidangi anak, perguruan tinggi, organisasi non pemerintah, lembaga swadaya masyarakat, sektor swasta, orang tua, dan anak. Bagi kabupaten/kota yang telah mempunyai Gugus Tugas/Tim/Pokja terkait dengan perlindungan anak tidak perlu membentuk gugus tugas baru namun harus menyesuaikan dengan keanggotaan dan uraian tugas Gugus Tugas KLA.

Tugas pokok dari Gugus Tugas KLA adalah: Mengkoordinasikan pelaksanaan kebijakan dan pengembangan KLA, Menetapkan tugas-tugas dari anggota Gugus Tugas, Melakukan sosialisasi, advokasi, fasilitasi dan KIE konsep KLA, Mengumpulkan data dasar, Melakukan analisis kebutuhan yang bersumber dari data dasar, Melakukan deseminasi data dasar, Menentukan fokus dan prioritas program dalam mewujudkan KLA, yang disesuaikan dengan potensi daerah (masalah utama, kebutuhan, dan sumber daya), Menyusun Rencana Aksi Daerah KLA (5 tahun) dan mekanisme kerja, Menyiapkan Peraturan Daerah tentang Rencana Aksi Daerah 
KLA; dan Melakukan monitoring, evaluasi dan pelaporan minimal 1 tahun sekali.

\section{Faktor-faktor pendukung dan penghambat dalam mewujudkan Kabupaten Pamekasan sebagai Kabupaten Layak Anak.'}

Dalam rangka mewujudkan Kabupaten Pamekasan sebagai Kabupaten Layak Anak, maka harus ada strategi dan indikator kebijakan pemerintah daerah, Strategi yang dapat dilakukan : (1) Menumbuhkan dan memaksimalkan peran kepemimpinan kabupaten/kota dalam memenuhi hak anak. (2) Mengembangkan pendidikan dan kesadaran publik mengenai visi baru tentang anak, (3) Mengembangkan kebijakan pemenuhan hak anak yang komprehensif, (4) Melakukan analisis situasi anak secara berkelanjutan untuk advokasi, perencanaan, monitoring dan evaluasi; (5) Membuat laporan tahunan kabupaten/kota tentang anak; (6) Membangun kemitraan dan memperluas aliansi untuk anak; (7) Memberdayakan keluarga melalui kelembagaan dan program pembangunan masyarakat; (8) Memperkuat jaringan untuk pemantauan pelaksanaan perlindungan anak dalam situasi khusus; (9) Memperkuat peraturan perundang-undangan dan pelaksanaan penegakan hokum; (10) Memberikan penghargaan kepada pimpinan daerah yang berhasil dalam melaksanakan kebijakan KLA.

Berikut indikator-indikator kebijakan KLA yang harus juga diperhatikan antara lain : (a) Adanya Bupati/Walikota yang mengembangkan Kabupaten/Kota Layak Anak di wilayah kerjanya; (b) Adanya kesadaran publik mengenai visi baru tentang anak; (c) Adanya kebijakan pemenuhan hak anak secara komprehensif; (d) Adanya hasil analisis situasi anak di setiap kabupaten/kota yang telah dipergunakan secara efektif dalam penyusunan program; (e) Adanya laporan kemajuan kabupaten/kota tentang pemenuhan hak anak; (f) Adanya kemitraan semua pihak dan aliansi untuk anak; (g) Adanya 
pemberdayaan keluarga melalui kelembagaan dan program pembangunan masyarakat; (h) Adanya jaringan untuk pemantauan pelaksanaan perlindungan anak dalam situasi khusus; (i) Adanya peraturan perundang-undangan dan penegakan hukum yang kuat; (j) Adanya Bupati/Walikota yang mendapatkan penghargaan sebagai pejuang Kabupaten/Kota Layak Anak; (k) Adanya institusi perlindungan anak

Pra-syarat pengembangan KLA adalah: (a) Adanya Kemauan dan komitmen pimpinan daerah: membangun dan memaksimalkan kepemimpinan daerah dalam mempercepat pemenuhan hak dan perlindungan anak yang dicerminkan dalam dokumen peraturan daerah; (b) Baseline data: tersedia sistem data dan data dasar yang digunakan untuk perencanaan, penyusunan program, pemantauan dan evaluasi; (c) Sosialisasi hak anak: menjamin adanya proses penyadaran hak anak pada anak dan orang dewasa secara terus menerus; (d) Produk hukum yang ramah anak: tersusunnya peraturan perundangan yang sesuai dengan prinsip-prinsip perlindungan hak anak; (e) Partisipasi anak: tersedia wadah untuk mempromosikan kegiatan yang melibatkan anak dalam program-program yang akan mempengaruhi mereka; mendengar pendapat mereka dan mempertimbangkannya dalam proses pengambilan keputusan; (f) Pemberdayaan keluarga: adanya program untuk memperkuat kemampuan keluarga dalam pengasuhan dan perawatan anak; (g) Kemitraan dan jaringan: adanya kemitraan dan jaringan dalam pemenuhan hak dan perlindungan anak; (h) Institusi Perlindungan Anak: Adanya kelembagaan yang mengkoordinasikan semua upaya pemenuhan hak anak; (i) Melalui strategi, indikator-indikator dan prasyarat tersebut, maka dapat diketahui tolok ukur hal-hal yang menjadi pendukung dan penghambat terlaksananya KLA di Kabupaten Pamekasan.

Faktor Pendukung segera terwujudnya Pamekasan sebagai Kabupaten Layak Anak adalah adanya kesamaan visi dari seluruh satuan kerja gugus tugas seperti dari Dinas 
Pendidikan, Pekerjaan Umum, Cipta Karya, Dinas Kependudukan dan Catatan Sipil, Dinas Kesehatan, stakeholder diluar pemerintahan yaitu ormas Islam dan umum, LSM, akademisi, dan Badan Perlindungan Perempuan dan Keluarga Berencana sebagai garda terdepan untuk mensukseskan Pamekasan sebagai Kabupaten Layak Anak. Begitu pula adanya komitmen Bupati dan Satuan Kerja Pemerintah Daerah tentang pemenuhan hak-hak anak yaitu melalui dana atau penganggaran terhadap kegiatan baik fisik maupun non fisik, penanganan kasus-kasus anak secara profesional dan berkelanjutan.

Sedangkan faktor penghambatnya yaitu belum dipahaminya tentang hak-hak anak/Kabupaten Layak Anak oleh Satuan Kerja Pemerintah Daerah, kurang komitmennya Satuan Kerja Pemerintah Daerah untuk mewujudkan Pamekasan sebagai Kabupaten Layak Anak, dan belum terkoordinasinya program-program yang menuju Kabupaten Layak Anak di masing-masing Satuan Kerja Pemerintah Daerah.

\section{Kesimpulan}

Berdasarkan hasil penelitian, maka dapat disimpulkan sebagai berikut:

1. Pemahaman tentang kabupaten/kota layak anak memberikan pengertian bahwa dalam rangka mewujudkan strategi pengembangan Kabupaten/Kota Layak Anak, diharapkan adanya komitmen bersama para stake holder dalam perwujudan KLA dan untuk mengetahui berbagai permasalahan anak yang muncul beserta upaya penyelesaian yang tepat. Hal utama yang harus dilakukan dalam mewujudkan KLA adalah memberikan prioritas dalam perencanaan penganggaran daerah akan kebutuhan pendidikan, tumbuh kembang dan perlindungan anak baik secara fisik maupun non fisik. Pemahaman seperti ini belum 
banyak dipahami oleh SKPD pemerintah daerah Kab. Pamekasan terutama yang masuk pada susunan gugus tugas KLA.

2. Penganggaran yang berasal dari Anggaran Pendapatan dan Biaya Daerah diusulkan kepada Tim Anggaran yang terdiri dari penganggaran Fisik, meliputi pengajuan shelter (rumah aman) berikut sarana dan prasarananya, Alat Permainan Edukasi (diajukan tiap tahun) sasaran atau penggunanya untuk kelompok Bina Keluarga Balita dan PAUD, pemberian makanan tambahan sekolah sasarannya untuk anak-anak Sekolah Dasar di 13 kecamatan se-Kabupaten Pamekasan. Non fisik, meliputi : Sosialisasi ke SKPD dan Tim Perencana, Rapat Kerja dengan instansi kerja terkait seperti dengan gugus tugas, sosialisasi dan pembentukan forum Anak, pendampingan melalui Pusat Pelayanan Terpadu Pemberdayaan Perlindungan Perempuan dan Anak, sudah dilaksanakan akan tetapi tidak dilakukan secara terpadu, masing-masing SKPD membuat rencana anggaran masing-masing. Masih ada SKPD yang belum memperhatikan perencanaan kegiatan yang berbasis pengarusutamaan gender (PUG) dan sensitifitas terhadap anak.

3. Target Pamekasan sebagai Kabupaten Layak Anak dapat terwujud dalam waktu kira-kira lima tahun. Beberapa hal yang harus dipersiapkan baik kebutuhan fisik dan non fisik. Persiapan yang harus dilakukan adalah Peraturan Daerah atau Peraturan Bupati, Rencana Aksi daerah menuju Kabupaten Layak Anak, hal ini adalah hasil komitmen Satuan Kerja Pemerintah Daerah (SKPD). Selain itu yang harus dipersiapkan antara lain adanya kesamaan visi dengan instansiinstansi terkait seperti Badan Lingkungan Hidup, Pekerjaan Umum, Cipta Karya, sedangkan Badan Pemberdayaan Perempuan dan Keluarga Berencana 
berada di depan untuk mengkoordinasikan dan menyiapkan kebutuhan dari hak-hak anak dalam rangka menuju Kabupaten Layak Anak.

4. Faktor Pendukung segera terwujudnya Pamekasan sebagai Kabupaten Layak Anak adalah adanya kesamaan visi dari seluruh satuan kerja gugus tugas seperti dari Dinas Pendidikan, Pekerjaan Umum, Cipta Karya, Dinas Kependudukan dan Catatan Sipil, Dinas Kesehatan, stakeholder diluar pemerintahan yaitu ormas Islam dan umum, LSM, akademisi, dan Badan Perlindungan Perempuan dan Keluarga Berencana sebagai garda terdepan untuk mensukseskan Pamekasan sebagai Kabupaten Layak Anak. Begitu pula adanya komitmen Bupati dan Satuan Kerja Pemerintah Daerah tentang pemenuhan hak-hak anak yaitu melalui dana atau penganggaran terhadap kegiatan baik fisik maupun non fisik, penanganan kasus-kasus anak secara profesional dan berkelanjutan. Sedangkan faktor penghambatnya yaitu belum dipahaminya tentang hakhak anak/Kabupaten Layak Anak oleh Satuan Kerja Pemerintah Daerah, kurang komitmennya Satuan Kerja Pemerintah Daerah untuk mewujudkan Pamekasan sebagai Kabupaten Layak Anak, dan belum terkoordinasinya program-program yang menuju Kabupaten Layak Anak di masing-masing Satuan Kerja Pemerintah Daerah.

\section{Daftar Pustaka}

Amalia Nugraheni, Novie, Sistem Pemidanaan Edukatif Terhadap Anak Sebagai Pelaku Tindak Pidana, Tesis Program Pascasarjana Ilmu Hukum Universitas Diponegoro Semerang, (10 Desember 2009) 
Hadi, Sutrisno, Metodologi Research, Yogyakarta: Andi Affist, 1990

J. Moleong, Lexy, Metodologi Penelitian Kualitatif, Bandung: Remaja Rosdakarya, 1990

Muhadjir, Noeng, Metode Penelitian Kualitatif, Yogyakarta: Rake Sarasin, 1996

Soekamto, Soerjono, Pengantar Penelitian Hukum, Jakarta : UI Press, 1988

Supraptiningsih, Umi, "Kesiapan Penegak Hukum Di Kabupaten Pamekasan Dalam Pemberlakuan UU No. 11 Tahun 2012 Tentang Sistem Peradilan Pidana Anak, Laporan Penelitian, 2014

Sutatiek, Sri, "Politik Hukum UU No. 11 Tahun 2012 tentang Sistem Peradilan Pidana Anak", Varia Peradilan, No. 328 (Maret, 2013)

http:/ / kla.or.id/index.php?option=com_content\&view=article \&id=214:kebijakan-pengembangan-kabkota-layakanak\&catid $=57$ : kepustakaan\&Itemid $=81$ diunduh Minggu, 8 Juni 2014 jam 14.48 WIB 